\title{
Making SENSE of Customer Service Experiences: A Text Mining Review
}

Citation for published version (APA):

Mahr, D., Stead, S., \& Odekerken-Schröder, G. (2019). Making SENSE of Customer Service Experiences: A Text Mining Review. Journal of Services Marketing, 33(1), 88-103. https://doi.org/10.1108/JSM-102018-0295

Document status and date:

Published: 01/01/2019

DOI:

10.1108/JSM-10-2018-0295

Document Version:

Publisher's PDF, also known as Version of record

Document license:

Taverne

Please check the document version of this publication:

- A submitted manuscript is the version of the article upon submission and before peer-review. There can be important differences between the submitted version and the official published version of record.

People interested in the research are advised to contact the author for the final version of the publication, or visit the DOI to the publisher's website.

- The final author version and the galley proof are versions of the publication after peer review.

- The final published version features the final layout of the paper including the volume, issue and page numbers.

Link to publication

\footnotetext{
General rights rights.

- You may freely distribute the URL identifying the publication in the public portal. please follow below link for the End User Agreement:

www.umlib.nl/taverne-license

Take down policy

If you believe that this document breaches copyright please contact us at:

repository@maastrichtuniversity.nl

providing details and we will investigate your claim.
}

Copyright and moral rights for the publications made accessible in the public portal are retained by the authors and/or other copyright owners and it is a condition of accessing publications that users recognise and abide by the legal requirements associated with these

- Users may download and print one copy of any publication from the public portal for the purpose of private study or research.

- You may not further distribute the material or use it for any profit-making activity or commercial gain

If the publication is distributed under the terms of Article $25 \mathrm{fa}$ of the Dutch Copyright Act, indicated by the "Taverne" license above, 


\title{
Making sense of customer service experiences: a text mining review
}

\author{
Dominik Mahr \\ Service Science Factory, Maastricht University, Maastricht, The Netherlands and Department of Marketing and \\ Supply Chain Management, Maastricht University, The Netherlands \\ Susan Stead and Gaby Odekerken-Schröder \\ Department of Marketing and Supply Chain Management, Maastricht University, Maastricht, The Netherlands
}

\begin{abstract}
Purpose - The purpose of this paper is to systematically review the concepts and theories underlying customer service experience (CSE) and its underlying five dimensions (physical, social, cognitive, affective and sensorial). In this research, the contribution of the sensorial dimension to CSE research is emphasized. Senses are especially important in forming perceptions within servicescapes that are typically rich in sensory stimuli.

Design/methodology/approach - This study systematically identifies 258 articles published between 1994 and 2018 in services and marketing journals. The analysis uses a text mining approach with the Leximancer software to extract research concepts and their relationships.

Findings - The results demonstrate a shift from CSE research focused on brands and products toward value and interaction, around three focal areas: service system architecture, with its value creation processes; servicescape, with an increasingly digital interaction interface and outcome measures, with a stronger focus on emotional and relational metrics. In CSE research, the physical, social and cognitive dimensions are mostly researched in the focal areas of servicescape and outcome measures. Although important in practice, the sensorial dimension is the least investigated CSE dimension in service marketing research. Text mining insights demonstrate rich opportunities for sensorial research, particularly in studies on servicescape.

Practical implications - The synthesis will inform managers and service providers which elements of CSE are most relevant to customers when forming perceptions. These insights help service providers to control, manage and design (multi)-sensory stimuli that influence how customers will make sense of the servicescape.

Originality/value - This research is one of the first studies to examine the conceptual structure of CSE with a text mining approach that systematically analyzes a large set of articles, therein reducing the potential for researchers' interpretative bias. The paper provides an assessment of the role of the largely neglected but crucial sensorial dimension, and offers future research suggestions into this emerging topic.
\end{abstract}

Keywords Customer experience, Multisensory, Sensory, Leximancer, Text mining, Review, Servicescape, Service research

Paper type Research paper

\section{Introduction}

With rapidly changing service landscapes, the need to understand, manage and design better customer service experiences (CSE) becomes inevitable for service managers and researchers alike (Roy, 2018). In total, 81 per cent of global marketers' report that they mainly compete on the basis of customer experience (Gartner, 2018). An increasing interest in this topic from both an academic and a managerial perspective has led researchers to recognize CSE as a research priority in contemporary services and marketing literature (Bolton et al., 2018; Jaakkola et al., 2015). A plethora of studies have recently emerged in services literature which identify CSE as a complex, multi-layered concept (Berry et al., 2002; Gentile et al., 2007;

The current issue and full text archive of this journal is available on Emerald Insight at: www.emeraldinsight.com/0887-6045.htm

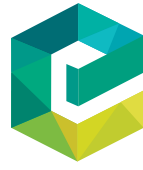

Journal of Services Marketing

33/1 (2019) 88-103

(C) Emerald Publishing Limited [ISSN 0887-6045]

[DOI 10.1108/JSM-10-2018-0295]
Helkkula, 2011; Klaus and Maklan, 2012; Lipkin, 2016; Pine and Gilmore, 1998; Schmitt, 1999) and recognize CSE as a cornerstone of marketing (De Keyser et al., 2015). Recent conceptual research on CSE defines it as a multidimensional construct consisting of physical, social, cognitive, affective and sensorial elements that encompass customers' direct or indirect interactions with a (set of) market actor(s) during the entire (purchase) journey (De Keyser et al., 2015; Lemon and Verhoef, 2016).

Despite these significant advancements on the conceptual nature of CSE (De Keyser et al., 2015), an over-focus on individual dimensions of CSE rather than incorporating all CSE dimensions simultaneously in one research has led to fragmented CSE research (Bustamante and Rubio, 2017; Lipkin, 2016). In the retail context, studies have strongly contributed to a better understanding of store atmospherics and product choices (Roschk et al., 2017; Yakhlef, 2015). Nevertheless, to the best of our knowledge, empirical studies in

Received 14 October 2018

Revised 27 November 2018

Accepted 28 November 2018 
the services context that have addressed all five suggested dimensions of CSE (i.e. physical, social, cognitive, affective and sensorial) are limited. Recent studies reveal that particularly little is known about the sensorial dimension of CSE (Bustamante and Rubio, 2017; Keiningham et al., 2017). This seems at odds with findings from consumer behavior studies where scholars, throughout the past decade, reveal the importance of visual, auditory, olfactory, taste and habitudinal stimuli on CSE in the retail context (Berry et al., 2002; Gentile et al., 2007; Holbrook and Hirschmann, 1982; Yakhlef, 2015). In a similar vein, a large variety of marketing studies have altered the servicescape to trigger sensory effects through aesthetic appeal, scents, music jingles, food samples and surface roughness (Krishna, 2012; Mattila and Wirtz, 2001). Drawing on literature from other domains such as psychology, neuroscience and cognitive science also provides diverse and rich insights about the senses. However, the large variety and scattered foci impede CSE researchers from manually synthesizing and translating these contributions to the services context.

In this article, we focus on the most recent conceptualization of CSE with its five corresponding dimensions. The aim of this study is to synthesize the rapidly growing contributions about CSE and its five dimensions across leading journals in the services and marketing domains. The following research questions guide our investigation:

$R Q 1$. What is the conceptual structure of CSE and how has it evolved over time?

RQ2. What theoretical concepts distinguish the five definitional dimensions of CSE?

RQ3. To what extent is the sensorial dimension present in CSE research?

RQ4. What concepts and theories of sensorial CSE cross the boundaries of services and marketing research and offer opportunities for future research?

Key motivations for this research are the need to understand, design and evaluate the five definitional dimensions of CSE, including taking advantage of the opportunity to o provide directions for service researchers to further advance this emerging field (De Keyser et al., 2015; Lemon and Verhoef, 2016; Lipkin, 2016; McColl-Kennedy et al., 2015). Using a novel text mining and topic modeling approach, we extract and consolidate the concepts and focal dimensions across a large set of articles in a rigorous, automated and systematic way. This is suitable for studying complex phenomena in an unbiased and content-driven format (Biesenthal and Wilden, 2014) - in particular, when contributions are cross-disciplinary, which is the case for CSE. The approach extracts word occurrences and applies a Bayesian algorithm to predict emerging concepts and their relationships, helping to better understand the research area, its development and research opportunities in the services marketing domain. In doing so, this article identifies important pathways to advance services research and CSE research in particular. It also guides future research studies that will ultimately help service managers to design services that create richer multisensory experiences for their customers.

\section{Customer service experiences and its underlying dimensions}

Multiple definitions of CSE exist across the services and marketing literature. This article focuses on the current, most accepted definition that considers CSE to consist of physical, social, cognitive, affective and sensorial dimensions (for further discussion, we refer to Lemon and Verhoef, 2016). Understanding the multidimensionality of CSE is a central focus of the emerging bodies of services, marketing and management literature (Lemon and Verhoef, 2016). Although there is widespread contemporary agreement on the importance of the concept of CSE, there are still divergent views on what constitutes CSE. In the past few decades, various research disciplines have presented an increasing number of scholarly articles showing different perspectives on (re-) defining, analyzing and capturing CSE (De Keyser et al., 2015; Helkkula, 2011; Klaus and Maklan, 2012; Lemon and Verhoef, 2016; Lipkin, 2016; Roy, 2018).

Reviewing these different perspectives on CSE research is helpful for understanding how scholars arrived at the five dimensions (physical, social, cognitive, affective and sensorial) of CSE. Literature reviews on CSE by Helkkula (2011) and Lipkin (2016) reveal that different theoretical lenses led to diverging approaches and characterizations of CSE. Helkkula (2011) views CSE literature as either process-based (i.e. papers concerned with the service system architecture), outcome-based (i.e. papers operationalizing outcome qualities) or phenomenonbased (i.e. papers view CSE as a holistic context-specific phenomenon). In contrast, Lipkin (2016) classifies CSE literature according to three levels of customer activity within the service environment. The first and most traditional perspective is stimulus-based, which refers to a passive response by the individual to largely controlled and created stimuli offered by the provider (Lipkin, 2016). This so-called Stimulus-Organism-Response (S-O-R) paradigm (Mehrabian and Russell, 1974) provides the theoretical grounds for these studies. The paradigm postulates that stimuli in the servicescape have an impact on customers' perceptions (organism), which leads to particular customers' reactions (responses). Some literature criticizes the S-O-R model, as it considers customers to be in a "passive state," implying that experiences are formed in an automated process (Pareigis et al., 2012; Lipkin, 2016).

The second interaction-based perspective extends the previous perception and views customers as active individuals that subjectively assess social interactions (Edvardsson et al., 2005; Pareigis et al., 2012). Studies classified as interaction-based have overcome previous limitations and identify customers' active role in sensing and interpreting the servicescape, which is driven by prior experiences (Lipkin, 2016). According to Lipkin (2016), the shortcomings of the interaction-based approach is the linear and temporal perspective that investigates CSE.

Finally, the most recent and advanced perception of CSE according to Lipkin (2016) is the sense-making-based perspective. In this view, studies understand CSE as a holistic and dynamic concept requiring iterative sense-making processes (Heinonen et al., 2013). Studies that apply this perspective investigate visible and invisible interactions within 
the servicescape (Bolton et al., 2014; Carú and Cova, 2015) with a large focus on customers' inner realism. Furthermore, customers understand the physical and social realities of the servicescape by engaging in cognitive and affective processes (Lipkin, 2016). It is notable that the sensory dimension remains essentially absent in this sense-making perspective. Outside the services context, studies on atmospherics reveal that environmental stimuli typically activate cognitive and affective processes (Roschk et al., 2017); however, the reasons behind customer reaction to such stimuli still remains unexplored (Rosenbaum and Massiah, 2011). As inner realism (Helkkula and Kelleher, 2010) to a large extent determines the cognitive and affective CSE dimensions, CSE may not always be externally observable. Spence et al. (2014) suggest that the sense-making process is a complex mechanism wherein experiences are not only transported by affective and cognitive iterations but are also affected, to a large extent, by sensorial iterations. The resulting perceptions cannot be understood on a sense-by-sense basis, but are the result of a multitude of cues in the servicescape that lead to a multisensory perception (Krishna, 2012), implying that customers selectively transfer multisensory cues by means of their senses into cognitive and affective perceptions (Spence et al., 2014). The complexity of inner realism makes it particularly difficult for services and marketing researchers to understand and capture the connected and holistic sensory experience in a complex service environment (Scott and Uncles, 2018). Given that senses play an important role in shaping CSE, we believe that the services discipline in particular would benefit from a clear conceptualization of the sensory dimension.

\section{Sensory dimension of customer service experiences}

When studying a concept as complex and interwoven as senses, it is essential to increase the understanding of the sensory phenomena and what "sensory" constitutes, exactly. Consumer behavior, psychology and neuroscience research have studied senses extensively (Driver and Spence, 2000; Streicher and Estes, 2016; Sunderland et al., 2012). To derive a common understanding of what senses and sensory perception entail, this article therefore first draws on well-established research beyond services literature.

Krishna (2012, p. 334) distinguishes between sensory stimuli and perception. Sensory stimuli are "stimuli that impinge upon the receptor cells of a sensory organ" and may appear as visual, auditory, olfactory, taste or habitudinal cues. Perception, on the other hand, is an "awareness or understanding of sensory information," which can be sensory, cognitive or affective. The concept of senses goes as far back as Aristotle, who introduced the theory of aesthesis (i.e. sensation) in the fourth century. Aristotle argued that the order of senses is hierarchical, starting with haptics and that all other senses increase the acuity of the touch sensation (Krishna, 2012). Later studies indicate that human perceptual systems can receive multiple sensory signals simultaneously, which can form in isolation or in combination as a starting point for further interpretation (Agapito et al., 2013).

Consumer behavior research relies extensively on insights of combined senses to assess product perceptions. For example, Orth and Malkewitz (2008) demonstrate the key role of vision and haptics for discovering changes in the environment and understanding product perceptions. Garlin and Owen (2006) also find a link between auditory (i.e. sound) impressions and the emotions and feelings that customers use as cues to interpret their experience (Hultén, 2011). In contrast, Dinh et al. (1999) show that olfactory and tactile cues increase customers' sense of presence and memory within a virtually depicted and perceived environment. Finally, the sense of taste is distinct and usually assessed in combination with other senses because humans can only distinguish five pure tastes (sweet, salty, sour, bitter and umami), so any inferred evaluation relies on a combination of sensory perceptions (Krishna, 2012). Ghanzanfar and Schroeder (2006) also find that the integration of senses across receptors (i.e. eyes, ears, nose, skin, taste) depends on the congruency of the stimulus signals. Rich simulations from different sources occurring simultaneously appear to refer to the same event (Driver and Spence, 2000). Against this academic background, substantial research in psychology and marketing highlights the impact of sensory stimuli or cues on customers' product perceptions.

However, in a services context, it is less obvious what role senses play in CSE formation (Scott and Uncles, 2018). In the broadest sense, services literature refers to the sensory dimension as the sense-making process of the customer when interacting with the physical service environment (Bitner, 1992). Berry et al. (2006) were among the few scholars who integrated the concept of sensory perception into a conceptual model. The authors captured senses within a mechanic clues dimension, which refers to environmental stimuli such as sights, smells, sounds, tastes and textures. This dimension is distinct from functional clues that pertain to the technical quality of the offering and human clues that emerge from the behavior and appearance of the service provider.

Building on these insights, Palmer (2010) later defines sensory stimuli in a way that is more centralized to the overall service experience by using Gupta and Vajic's (2000) definition stating that CSE results from any sensation or knowledge that customers derive from an interaction with different elements in the context created by the service provider. Palmer (2010) not only confirms the importance of the services context as a driver of CSE but also suggests that customers perceive sensory stimuli in a manner unique to the individual - this applies to sensory perceptions in isolation as well as in combination. In fact, cues in a services context often are perceived as multisensory stimuli, (e.g. a combination of taste and smell), where multiple senses drive cognitive and affective perceptions (Krishna and Schwarz, 2014; Sunderland et al., 2012; Yanagisawa and Takatsuji, 2015).

Although the contributions of marketing and psychology research lead to a clearer understanding of multisensory perception, these studies mostly adopt a product perspective. However, much work still needs to be done to understand the impact of the multisensory CSE (Keiningham et al., 2017; Scott and Uncles, 2018). In line with this idea, Krishna (2012) shows how subconscious triggers appealing to customers' senses affect their perceptions and induced behavior; substantial literature also identifies the effects of the senses on customers' purchasing behavior (Adolphs et al., 2000; Bolton et al., 2014; Peck and Childers, 2008). In particular, Yanagisawa and Takatsuji (2015) note that sensory stimuli lead to multisensory perceptions, which affect posterior emotions. 
This finding suggests that sensory stimuli drive cognitive and affective perceptions of CSE; as of yet, however, there is no universally accepted or integrated conceptualization of the sensorial dimension in CSE research.

In the services context in particular, reliance on sensory cues is crucial; services do not offer any tangible cues that customers can use to judge the experience (Kwon and Adaval, 2018). In fact, sensations that are derived from sensory organs (i.e. eyes, ears, nose, skin and taste receptors) and "act as the initiator of individuals' perception of the surrounding world, a process through which sensory inputs are selected, organized, and interpreted, resulting in a conscious sensory experience" (Agapito et al., 2014, p. 225). Additionally, empirical studies emphasize the importance of the sensory dimension over the other four dimensions of CSE, suggesting that the role of the senses is key for value-creation processes in the servicescape (Agapito et al., 2014; Brakus et al., 2009; Gentile et al., 2007). Thus, it is essential to broaden perspectives on this topic and draw on well-established marketing and psychological research streams to cross research boundaries and shed some light on this complex and most relevant dimension of CSE.

\section{Methodology}

CSE has gained prominence in the services and marketing discipline over the past years, with a broad set of published studies (Bustamante and Rubio, 2017). To consolidate scholarly understanding about the concept and its underlying foundations, certain initial papers reviewed the concept; however, either they did not follow a systematic approach or they based their analyses on manual coding (Lipkin, 2016) which might be subject to researcher bias (Wilden et al., 2017). The current study uses a systematic text mining and machine learning approach with the aim of expanding the scale and scope of existing CSE reviews. Text mining is a form of unstructured ontological discovery (Randhawa et al., 2016) that consolidates concepts and themes across a large set of articles in a rigorous, automated and systematic way, particularly suitable for studying complex phenomena in an unbiased and content-driven format (Biesenthal and Wilden, 2014).

This article makes use of the Leximancer 4.0 software, which applies a Bayesian learning algorithm to identify word cooccurrence frequencies as well as relationships within the text corpus that have been used in other contexts. Put simply, words that occur frequently make up a concept; concepts that "cooccur", often within the same sentence, are clustered in close proximity and grouped to a theme (Cretchley et al., 2010). Thus, the themes explain the groupings of the clusters and are named after the most prominent concept in the cluster. Leximancer uses a clustering algorithm that outperforms other approaches such as latent dirichlet allocation (LDA), as it does not decide on the number of themes prior to the analysis, but rather selects the number of themes through a machinelearning algorithm based on the discovered concepts and their relationships (Wilden et al., 2017).

\section{Sample selection}

To comprehend the status quo and evolution of CSE research as rooted in marketing and emerging services literature, we used Thompson Reuters' InCite Citation Index and Web of
Science to identify relevant journals and CSE articles. The citation index allowed us to identify peer-reviewed services and marketing journals which were ranked according to the impact factor. For our analysis, we included services and marketing journals with a five-year impact factor higher than one (IF > 1). In total, 16 services journals and 27 marketing journals met the initial criteria and were consolidated based on four main criteria, outlined in the next section.

The next step, a keyword search in Web of Science, including all 43 journals was conducted. For the selection of keywords, we made use of peer discussion with experienced researchers in the field. As a result, we defined a list of the most relevant keywords for CSE research, which were used in an issue-by-issue search of all selected journals. The search proceeded in two stages. First, we searched in all journals for the terms "customer experience," "user experience," "service experience" or "experience centric service" in the title, abstract and keyword section. This restriction ensured that CSE was the focal concept in the articles. As we were particularly interested in the sensory dimension of CSE, in the second search step, we investigated the same set of journals by using a search for the following combination of words: "senses AND experience" or "sensory AND experience" or "sensorial AND experience" or "multisensory AND experience" or "multisensory AND experience."

Given the aim of this article, the results of the data search served to generate a comprehensive list of papers that have been conducted in the corpus of CSE literature across decades; in addition, it reveals those papers that have contributed to the sensorial dimension. Thus, for an article to be included, the following criteria had to be met:

- published in English language;

- contains at least one of the search words in the title, abstract or keyword section;

- published and available in any online archive or database; and

- considered a full article (e.g. calls for papers, abstracts or proceedings were not included).

The search resulted in an initial set of 331 articles: of which 151 belong to marketing journals and 180 to services journals (Figure 1). The authors independently scanned all 331 articles to ensure that they met the inclusion criteria and that the focal concept was CSE and/or the concept of senses in the context of CSE. In particular, the articles had to meet one of the following criteria: it had to provide a definition of CSE or senses; it provides a conceptualization of CSE or senses or it provides dimensions of CSE or senses. The coding resulted in an overlap of 93 per cent. For the articles where the coders did not come to an agreement a third, independent coder was involved. This coding process led to a final sample of 258 articles (73 excluded). Of these 258 articles, 206 CSE articles resulted from the first search and 52 sensorial-related articles resulted from the second search.

\section{Text mining analysis}

The first two steps in the data analysis phase included downloading all 258 articles from the journal database and converting PDFs into Microsoft Word files. This step removed reference lists and any headers and footers stating the article title, journal name, authors or year of publication, and page 
Figure 1 Overview of systematic literature review

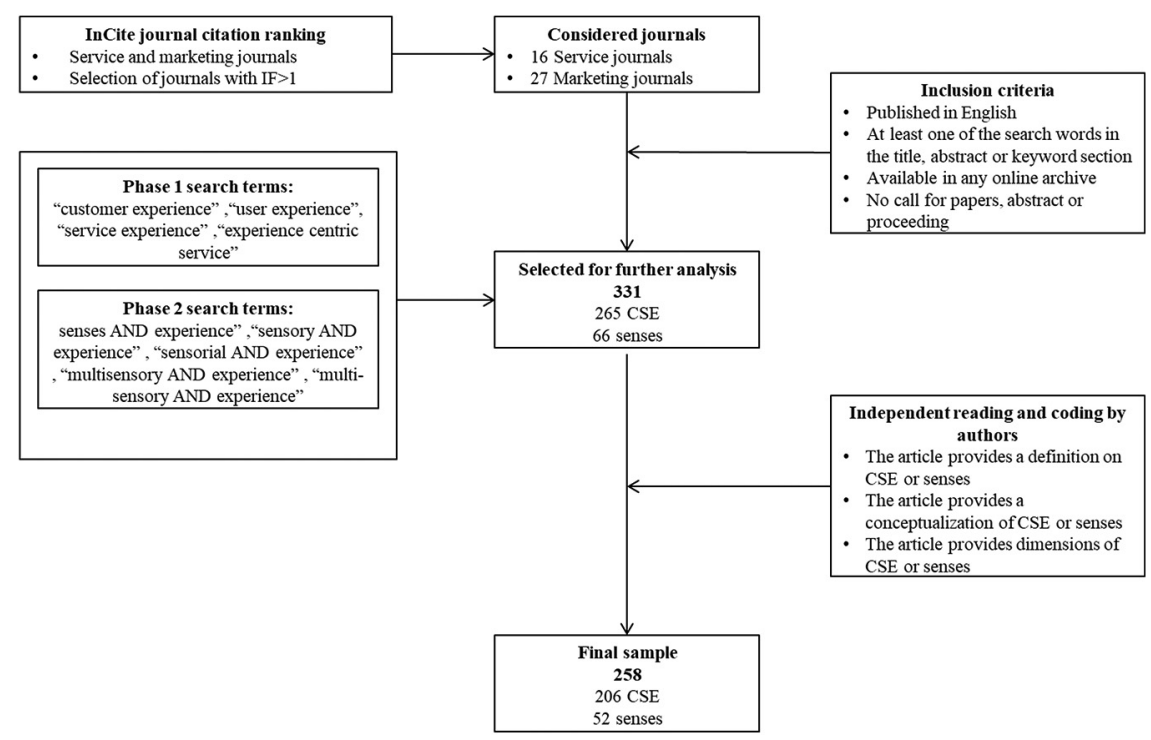

numbers to avoid causing meaningless or biased cooccurrences of words after running the analysis (Netzer et al., 2012). The data set was then clustered into publications on CSE that occurred between 1994-2008 and 2009-2018. The first publication that matched our search criteria was found in 1994. Drawing on Lemon and Verhoef's (2016) influential article, the authors find that although Schmitt (1999) already identified five types of experiences [i.e. sensory (sense), affective (feel), cognitive (think), physical (act), and socialidentity (relate) experiences], only ten years later, Brakus et al. (2009) introduced the sensory dimension as the fifth dimension to the CSE definition. We therefore anticipate a potential conceptual shift in CSE research as of 2009. For the 52 articles that matched our sensory keyword search, we did not split the set into different time frames, as our intention was to reveal a detailed overview of key concepts that can help define the multisensory dimension in CSE research.

The analysis with Leximancer resulted in a semantic extraction of a thesaurus of words that carry related meanings and form a theme (Randhawa et al., 2016). Thus, the output of the software procures are visual and tabular representations of concepts, themes and their relationships (Liesch et al., 2011). As such, the software identifies closely related concepts and clusters them in a theme. The relative size and color refer to the relative importance of the themes, which follow the color wheel with red determining the most important theme. The distance between concepts gives an indication of the semantic relationships, meaning that strongly connected concepts appear in close proximity (Smith and Humphreys, 2006). Additionally, when interpreting the graphic depiction, an important element to consider is the presence, or most importantly, the absence of a concept. Following Liesch et al.'s (2011, p. 25) reasoning, it may be "potentially instructive if important concepts fail to occur sufficiently frequent within the text to be identified and associated with other concepts." Although Leximancer follows an unsupervised learning algorithm, thesaurus generation (through, for example, concept seed word cleaning, classification of conceptually synonymous concepts and the interpretation of the graphical depiction) is an important action that is still undertaken by the researcher.

We excluded general terms (such as research, results, showed, significant and model) which are commonly used throughout articles, but do not specifically add meaning to the content analysis (Cretchley et al., 2010). In addition, singular and plural words were merged (such as environment and environments). Finally, we excluded our search terms "customer," "experience" and "service" as they would logically dominate the results and could blur the underlying concepts and themes of CSE we are interested in.

\section{Findings}

\section{Evolution of themes and concepts in customer service experience research}

Comparing and interpreting the graphical depiction and tabular insights from CSE publications between 1994-2008 (T1) and 2009-2018 (T2) helps to address RQ1. Specifically, we interpret themes, concepts and their semantic distance and read samples from the focal articles that form these themes (Randhawa et al., 2016). To understand how the field of CSE research has evolved, we investigate whether prominent themes and concepts have changed.

First when investigating T1 $(n=31)$, it is noted the semantically closely related and most noticeable themes are brand and consumer, and to a slightly lesser extent interaction (Figure 2), indicating a strong provider- and product-centric focus. Specifically, the most dominant theme brand in $\mathrm{T} 1$ consists of concepts such as marketing, business, firms and industry. The close proximity between the concepts of product, brand and value, support this product-centricity. The connection to the second most prominent theme consumer can be observed through the concepts of firm and relationship. Furthermore, central concepts in customer-firm relationship studies entails consumer satisfaction, along with positive and negative evaluations as outcome variables (Patrício et al., 
Figure 2 Time 1 (T1: 1994-2008)

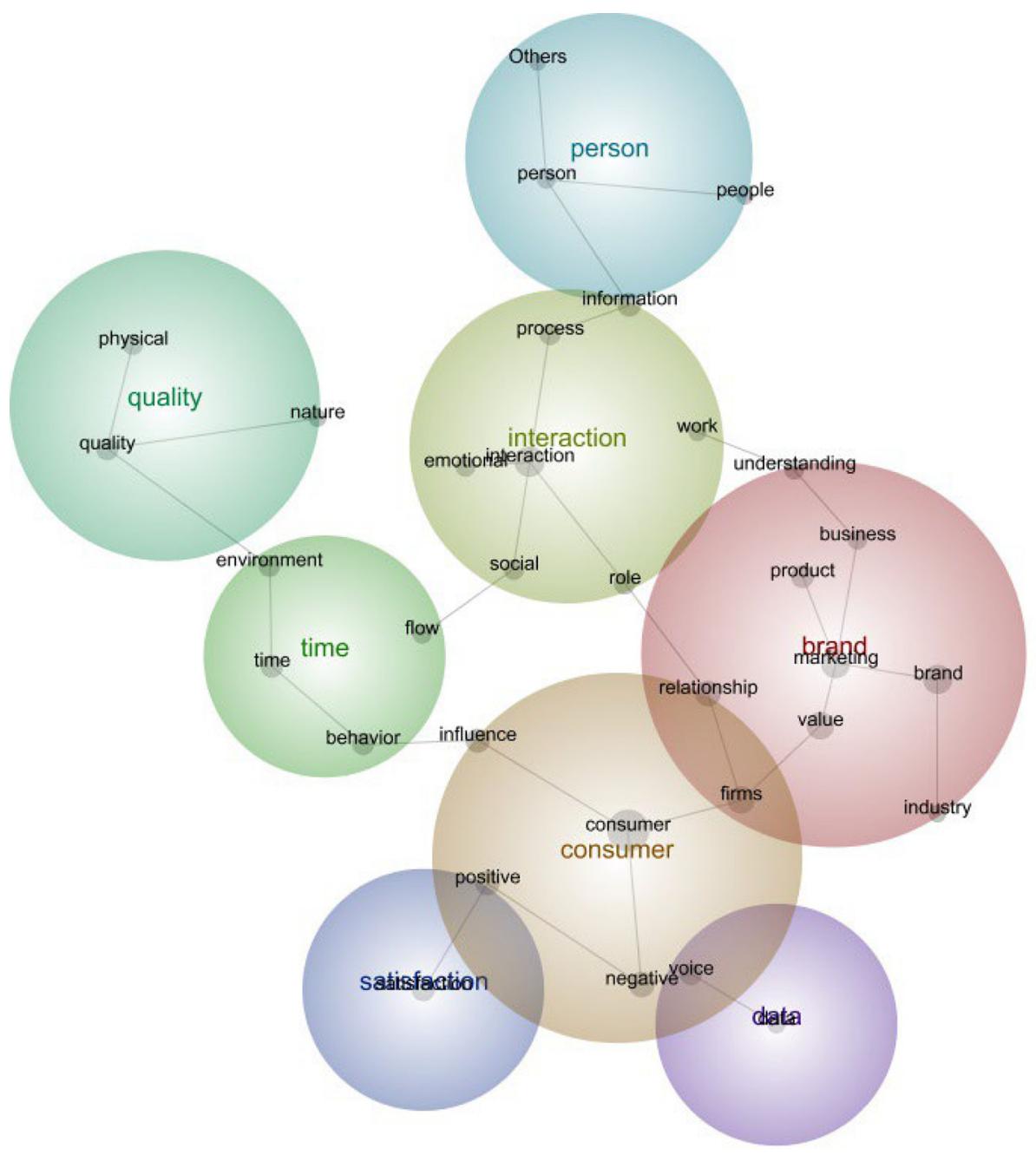

2011). According to Palmer (2010), customer satisfaction and quality have been criticized for their shortcomings in predicting purchasing behavior and bias toward cognitive outcomes as opposed to affective outcomes.

With the development of the service-dominant (S-D) logic (Vargo and Lusch, 2004, 2008) within the period of T1, customer-centricity and broader perspectives on the servicescape and service interactions became prominent (Lipkin, 2016; Nenonen et al., 2018; Rosenbaum and Massiah, 2011). Themes of interaction and quality include three of five CSE dimensions: physical, social and affective (i.e. emotional). The emotional and social dimensions are mostly associated with interaction, whereas the physical dimension is related to quality.

As a relatively new emerging research area, it is not surprising that the majority of CSE articles $(n=175)$ fall under the second period: 2009-2018 (T2). Two formative CSE studies appeared in 2009 and 2010, which demonstrate the change and broadening of the research focus (Brakus et al., 2009; Zomerdijk and Voss, 2010). Their CSE definitions now encompass the sensory dimension as the fifth dimension. In addition, CSE has shifted from a dyadic provider-customer focus to a much broader concept that is subject to influence from the interaction within the servicescape with contextual stimuli, which is not necessarily controlled by the provider (Rosenbaum and Massiah, 2011). In this vein, CSE is understood to be shaped on the basis of physical, social, cognitive, affective and sensory perceptions (Bolton et al., 2014).

In line with these changes, several new themes emerge in T2. Zooming into the conceptual map of Figure 3, we identify three key areas of CSE research that enable a better understanding on the evolution and current state of CSE research. Figure 3 shows the key areas through three circles, which summarize concepts relating to the service system architecture (circle A) (Patrício et al., 2011), servicescape (Bitner, 1992; Rosenbaum and Massiah, 2011) (circle B) and outcome measures (Helkkula, 2011) (circle C). The following explains each research area further.

\section{Service system architecture}

Research on service system architecture focuses mostly on two dominant themes: value and processes. The themes data and information are somewhat distant, but can be seen as support 
Figure 3 Time 2 (T2: 2009-2018)

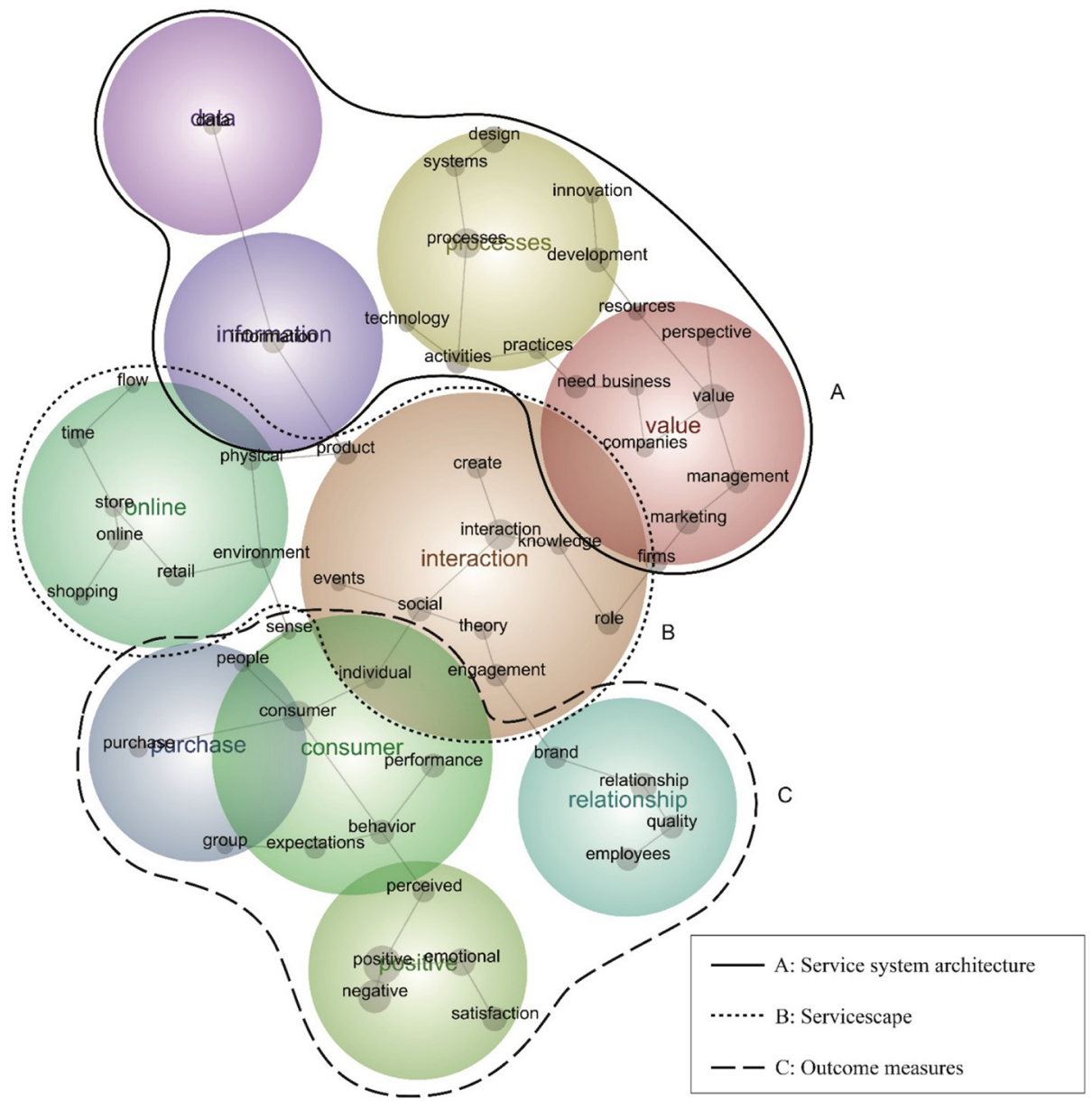

processes. Surprisingly, the theme of value in T2 is now detached from the consumer theme, and in turn dominantly connected to provider-related concepts. In close proximity are concepts such as company, management and marketing. Additional concepts include resources and perspectives. Furthermore, the closely connected concepts of business, companies and need, along with perspective and resources, link to the second largest theme of processes. Processes can be described by not only systems, technology, activity and practices but also innovation and development. The relatively close proximity between the concepts design, system, innovation and development constitute an important change to $\mathrm{T} 1$ and have been identified as key concepts for creating meaningful value propositions ( $\mathrm{Yu}$ and Sangiorgi, 2017).

This is different from $\mathrm{T} 1$ where processes (showing as a concept) appear scarcely addressed under the theme of interaction, which is now directly linked to the theme of value and more distant to the theme interaction. In contrast to T1, an interesting finding is that the theme brand and the concept relationship is no longer in close proximity to the theme value. Instead, brand is now a concept under the separate theme relationship in $\mathrm{T} 2$, which can be considered an outcome measure of CSE (circle C).

\section{Servicescape}

The second area of research constitutes concepts that focus on the servicescape. The servicescape is defined as a physical setting in which a service exchange is performed, delivered and consumed (Bitner, 1992). Interaction and online are two of the central themes that emerge from the analysis of T2, where interaction can be considered the key activity in CSE research taking place in the servicescape (Patrício et al., 2011). Additional concepts include role, create and knowledge. Comparing T1 and T2, role is one of the few concepts that remain rather stable in both size and position. This concept is captured in both $\mathrm{T} 1$ and $\mathrm{T} 2$ under the theme interaction, and in close proximity to provider-related concepts, indicating a rather constant research interest across time. This finding supports the notion of redefining actors' roles in the servicescape (Patrício et al., 2011). Under the service logic, it has been shown that the actors' knowledge and understanding of their role in the servicescape significantly influences value creation processes (Moeller et al., 2013; Wetter-Edman et al., 2014). Interestingly, the social dimension of CSE links to theory, which in turn links to engagement. In line with this, engagement theory has recently been shown to include and refine actors' engagement in the servicescape ( $\mathrm{Li}$ et al., 
2018). Also engagement and the individual constitute dominant concepts that bridge the servicescape themes with themes related to outcome measure.

The second most dominant theme in the servicescape online is an important change to the servicescape literature in general. Online did not emerge as a concept in the analysis of $\mathrm{T} 1$, but now forms a relatively large theme under T2. Concepts of time, flow store, shopping and retail represent the clear shift toward an online environment in the retailing industry. In comparison to $\mathrm{T} 1$, where the physical dimension was associated with the concept of quality, T2 observes a strong shift toward an online environment.

\section{Outcome measures}

In the third research area that describes as outcome measures, themes that emerge are consumer, relationship, purchase and positive (Figure 3). While consumer and purchase are clustered in close proximity, concepts such as expectations, behavior, performance and purchase shape these themes. In line with Helkkula's (2011) characterizations, these studies expand the scope of CSE toward largely measurable outcome variables. Furthermore, we found a link between consumer and perception, positive and negative evaluations and satisfaction (Svari et al., 2011). Interestingly, satisfaction receives less attention in T2 as opposed to T1 where it is a theme itself. Additionally, the concept of emotions shifts from the servicescape, where it is closely linked to interaction, toward an outcome measure concept. In addition, the concept of sense appears under the consumer theme and is closely connected with the concept of environment in the servicescape.

A new theme labeled relationship emerges in T2. Moreover, brand, quality and employees play a central role in relationship building and maintaining (Nguyen et al., 2014). In particular, quality and brand have received far less research attention in comparison to $\mathrm{T} 1$.

\section{The five dimensions of customer service experiences}

To answer $R Q 2$, we compared and assessed the five dimensions of CSE across both periods. As outlined in the methodology section, the sensory dimension appeared in CSE definitions only as of 2009, whereas earlier CSE studies addressed the other four dimensions (Lemon and Verhoef, 2016). Interestingly, when investigating Figure 2 (T1), only three (social, affective and physical) of the five dimensions appear as concepts. While under the interaction theme, social and affective factors seem to play a large role, whereby the physical dimension was tied in with the theme of quality. Surprisingly, the cognitive dimension (and as anticipated the sensory dimension) is absent. More importantly however, in T2 (Figure 3), an indication for four of five dimensions can be found. The physical dimension is closely connected to the environment, whereas the social dimension remains a key concept of interaction. In contrast, the affective dimension (i.e. emotion) has shifted toward consumer evaluations that are measurable as CSE outcomes.

The concept sense is somewhat positioned between the themes of online and interaction, and at the edge of the consumer theme circle. As the concept does not directly state itself as "sensory," it could infer multiple meanings. As a result, an additional investigation was conducted. Reading text examples provided insights indicating the concept sense relates to both sensing and senses. Thus, we find a connection between the (online) environment and consumer senses, but no connection related to the sensory dimension. Surprisingly, the cognitive dimension remains absent in the output of $\mathrm{T} 1$ and $\mathrm{T} 2$, indicating that little or no attention has been paid to this dimension. As the aim of $R Q 3$ and $R Q 4$ focused on the sensory dimension, we conducted a second text mining analysis.

\section{Multisensory customer service experiences}

The second step of the analysis focused on papers that investigate the sensory dimension $(n=52)$. The analysis of these articles is necessary for answering RQ3 and RQ4. First, product is revealed to be the most dominant theme in Figure 4. In contrast, service is only a relatively small concept under the theme of experience, indicating that limited attention has been paid in sensory experience research. The sensory concept is the most prominent and closest connected concept under the theme product (Figure 4). Furthermore, all five human senses are in relatively close proximity to the theme product as opposed to experience or the service concept. Vision and touch constitute the concepts of product and are closely related to packaging, association and perception. Somewhat unrelated to the product theme are sound (i.e. hearing) and taste, which can be considered individual themes. Taste is strongly related to the concept of smell and food, indicating that studies have focused on these two senses in the conjoined context of food (Krishna, 2012). Another interesting finding is that the theme of sound is related to color, which appears separately from vision. Vision is closely connected to the theme of brands. In contrast to Figure 2 (T1) and Figure 3 (T2), Figure 4 reveals that all five dimensions of CSE are visible. This shows that studies investigating the sensory dimension of CSE also consider the other four dimensions.

In contrast to the five human senses, which are mostly investigated with products and brands; four of five CSE dimensions occur adjacent to the theme experience. In particular, the concepts emotion and cognition appear under the theme of experience. Surprisingly, cognition is linked to positive (a theme that relates to outcome measures) and experiences, indicating importance in both areas. The social dimension forms a separate theme, constituting solely of the concept physical. Both dimensions (i.e. social and physical) connect to experience. In contrast, emotions closely relate to processes and purchase, which are outcome measures (Figure 3, $\mathrm{T} 2$ ). In a similar vein, the concept affective, which consists of emotions, closely relates to the themes of brand and product; concepts such as positive, negative and quality occur in close proximity.

Surprisingly, the sensory concept is the only one out of the five dimensions that does not directly link to experiences or service. In fact, the sensory concept links to consumers, which is a concept that is part of both themes: product and experience. In Figure 4, the concept of "customer" is mostly associated with services, whereas "consumer" is more connected to products. The distance between the sensory concept and the themes service and experience hints that limited research has been conducted in the service literature. This finding supports the observation across $\mathrm{T} 1$ and $\mathrm{T} 2$, where the sensory dimension is absent. 
Figure 4 Sensory experience research

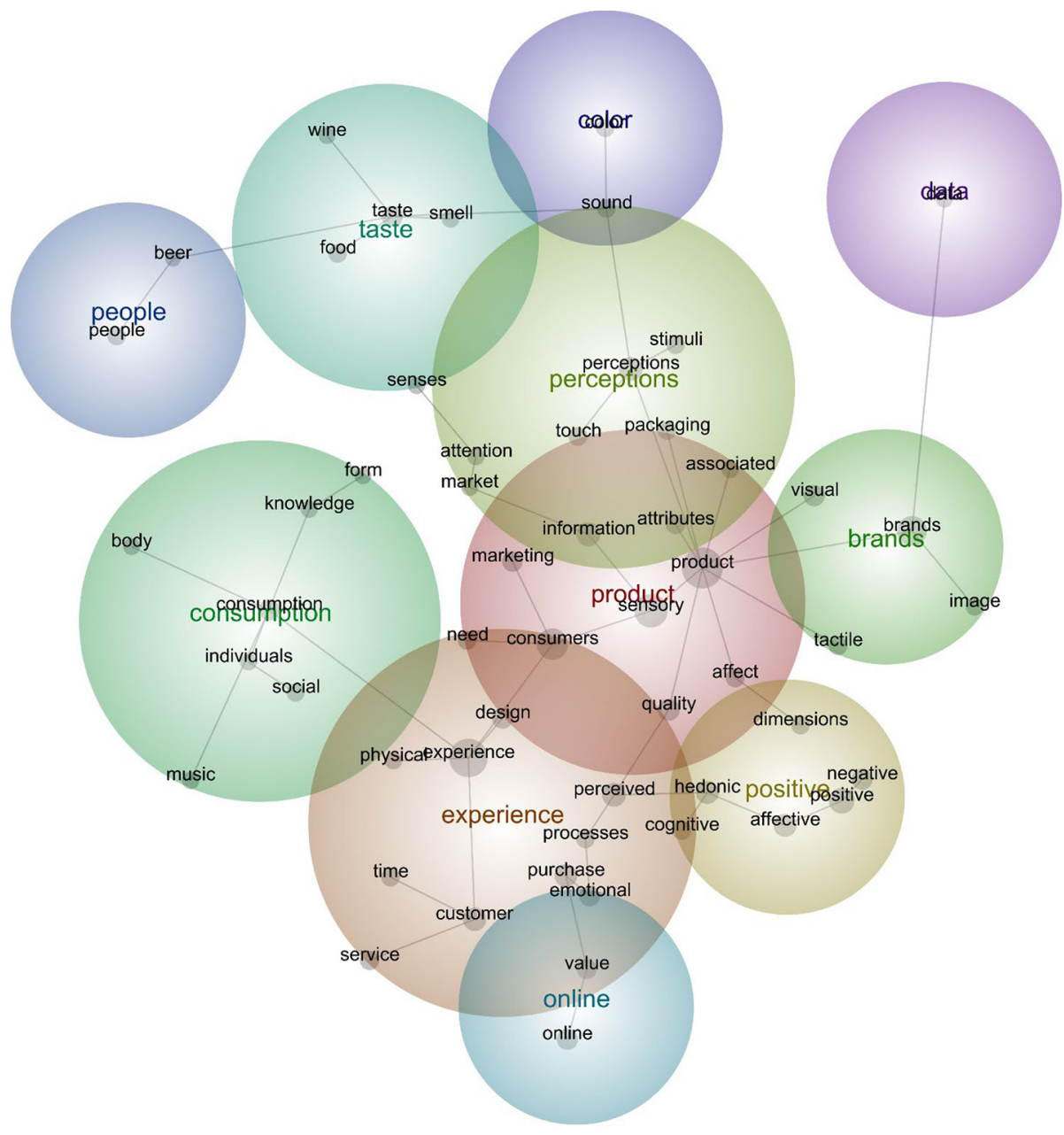

The analysis of the sensory literature shows that the sensory dimension relates strongly to information, indicating that information is retrieved through sensory processing (i.e. through human senses). Senses cluster as a concept under the theme of consumption, indicating an important role for consumption processes. Furthermore, vision and touch (in theme product) closely link to perception and association.

\section{Discussion and implications}

This study identifies pathways for developing CSE research via its central concepts and dimensions (Bustamante and Rubio, 2017). In particular, the sensory dimension in the CSE research remains a key challenge for researchers and practitioners alike (Scott and Uncles, 2018). The text mining analysis offers a novel approach in analyzing diverse contributions to CSE research over time and identifies three distinct research areas: service system architecture, servicescape and outcome measures.

The findings clearly reveal a lack of research attention on CSE's five fundamental definitional dimensions (i.e. physical, social, cognitive, affective and sensorial). In fact, only the physical, social and affective dimensions are found consistently across both periods (Figures 2 and 3), with only weak indication for the sensory dimension in T2. The social and physical dimensions constitute important concepts related to a fundamental change between $\mathrm{T} 1$ and $\mathrm{T} 2$, where a shift from product and firm perspectives in $\mathrm{T} 1$ toward interaction and value creation in T2 can be observed. These observations lend support to the suggested shift from manufacturing-dominated economies, where experiences involve customers who transform tangible products into value (Palmer, 2010; Schouten et al., 2007; Vargo and Lusch, 2004). Recently, service ecosystems are seen as being more dynamic (Wilden et al., 2017), where particularly the servicescape should facilitate richer value creation.

In a similar vein, the analysis reveals that most research attention lies on the processes (Figure 3 circle A) that support the value propositions (circle B) and the interaction within the servicescape (circle B). Andreassen et al. (2016) suggest that designing value creating services requires the provider to understand processes and contexts that influence CSE. This means that firms should develop value propositions and constellations from which the customers can derive value (Gupta and Vajic, 2000). The close connection between value and processes is further elevated in service design, an approach that has received increasingly more attention in the services literature over the past years (Antons and Breidbach, 2018). 
Service design emerges as an approach that enables organizations to communicate, plan and organize people and resources to develop better services (Mager, 2009).

While the link between processes and value are important, the findings suggest that the role of the customer seems somewhat neglected, which is indicated by the distance between the themes (Figure 3). This may be seen as contradictory to the S-D logic's foundational premises (FP) 6 stating that "value is co-created by multiple actors, always including the beneficiary" and FP7: "actors cannot deliver value but can participate in creation and offering of value propositions" (Vargo and Lusch, 2016, p. 8). This discrepancy resonates with Wilden et al.'s (2017) discussion on how to structure value networks and resource configurations to enable service innovation (Karpen et al., 2015).

Another development in CSE research can be observed in the physical dimension of T2, which is conceptualized under the emerging theme online in the servicescape (Figure 3, circle B). In fact, scholars have recently called for broader perspectives on the servicescape that capture customer activities at different physical places and moments in time (Heinonen et al., 2010), e.g. investigating CSE in an online environment in comparison to retail store environments (Moody et al., 2014; Trevinal and Stenger, 2014). Li et al. (2018) suggest that taking an actors' perspective enables a broader view on CSE at various points in time and places, such as virtual or online environments (Moody et al., 2014). This technology-driven shift toward omni-channel usage (Grewal et al., 2017) necessitates more research to reach a better understanding of CSE and its dimensions in this rapidly emerging and complex context (Spence et al., 2014; Trevinal and Stenger, 2014). In T2, the analysis found that the social dimension receives more attention and plays a key role in the interaction linking the servicescape with the individual consumer. The emotional dimension is no longer considered in the servicescape, but receives research attention with regards to outcome measures of CSE in T2. Most importantly, however, the sensory and cognitive dimensions seem rather disregarded in CSE research. The concept of sense emerges under the theme consumer in close proximity to interaction and online, indicating that senses might play an important role for the servicescape. This could ultimately provide outcome measures for customers. We cannot find evidence for the cognitive dimension in T1 and T2. This finding can either be interpreted in that the dimension has been captured through other less prominent concepts in CSE, or that there is a lack of research capturing cognition in CSE research.

As the focus of this study is on the sensory dimension of CSE, the analysis of sensory dominant studies reveals further insights (Figure 4). The articles in the sample show a strong product focus, where all five human senses are closer connected to the theme of product as opposed to experience or the limitedly represented concept of service. Although scholars have stressed the importance of multisensory perception in CSE (Brakus et al., 2009; Scott and Uncles, 2018), only two of five human senses (e.g. taste and smell; hearing and vision; touch and smell) show a connection and suggest a conjoint investigation in future research. Interestingly, the findings reveal that senses are mostly investigated with products and not services. The analysis discloses that next to shaping product and brand perceptions; senses play a key role for consumption. In fact, Agapito et al. (2014) notes that studies have stressed the importance of the sensory dimension in CSE as opposed to the other four dimensions in that they are key to the interaction and co-creation of value (Prahalad and Ramaswamy, 2004). Surprisingly, interaction is not considered a concept in sensory CSE research and likewise, only an indication of the importance of senses emerges from the findings in T2. Comparing insights from T2 and the sensory CSE research, it is suggested that senses could play an important role linking the servicescape and the sense-making process of the customer (Lipkin, 2016). This is classified in T2 as outcome measures. Indeed, a wide range of studies has revealed the importance of senses with regards to forming knowledge and understanding the environment (Agapito et al., 2014; Krishna, 2012), yet it seems that CSE research is relatively underrepresented on its sensory dimension.

In sum, it is noticeable that academics have largely broadened the perspective on what constitutes CSE and shifted from a dominant product and provider perspective toward an interaction and value perspective (Vargo and Lusch, 2016; Lusch et al., 2016). Although three (i.e. physical, social and affective) of the five CSE dimensions received more attention in $\mathrm{T} 2$, especially the cognitive and sensory dimensions fall short in service literature. Our analysis reveals that senses play an important role in generating knowledge about products and brands (Figure 4). This suggests that the cognitive and sensory dimensions are closely connected and relevant for customers to form their perceptions. The sensory focused analysis highlights several important insights that could benefit the services context. Combining these insights, the following sections highlight research gaps and develop important research questions, which should serve as direction for advancing CSE and service research.

\section{Avenues for future research}

Although the five dimensions of CSE have been identified almost 10 years ago (Brakus et al., 2009), the results of this study clearly show that CSE research has paid limited attention to its underlying dimensions and their impact on the service system, in particular the sensory and cognitive dimensions lack research attention. Accordingly, this sections presents five future research avenues along with potential research questions (Table I) that should guide future services and in particular, CSE researchers.

\section{Develop a more comprehensive understanding of the five dimensions of customer service experiences} The social, physical and sensory dimension show a close connection to the themes of interaction and the online environment (Figure 3), which highlights its importance for the servicescape. The affective dimension appears across all three analyses as being closely connected to CSE outcome measures. A recent study by Bustamante and Rubio (2017) defines the customer internal responses to the environmental stimuli as cognitive, affective and physical, while the social dimension appears as an external response toward other actors within the servicescape. While this study advances earlier models that aimed to capture CSE (Klaus and Maklan, 2012), two limitations emerge that - in line with findings in the present 
Table I Avenues for future research

\begin{tabular}{|c|c|c|}
\hline Research direction & Research questions & Selected references \\
\hline CSE & $\begin{array}{l}\text { Which of the five dimensions of CSE (i.e. physical, social, } \\
\text { affective, cognitive and sensorial) is the most relevant in } \\
\text { the service setting? } \\
\text { What is the relationship between the CSE dimensions (e.g. } \\
\text { hierarchical or sequential)? } \\
\text { How can sensory stimuli and perception be integrated in } \\
\text { omni-channel marketing? } \\
\text { What innovative research methods can be used to } \\
\text { investigate multisensory CSE (e.g. sensory ethnography; } \\
\text { sensory anthropology)? }\end{array}$ & $\begin{array}{l}\text { De Keyser et al. (2015), Lemon and Verhoef (2016), Roy } \\
\text { (2018), Scott and Uncles (2018) }\end{array}$ \\
\hline Service system architecture & $\begin{array}{l}\text { How can service providers leverage CSE's dimensions } \\
\text { when reconfiguring service processes? } \\
\text { Which dimensions of CSE are most relevant for innovating } \\
\text { service systems? } \\
\text { How can service providers design and manage } \\
\text { multisensory rich value propositions? }\end{array}$ & $\begin{array}{l}\text { Agapito et al. (2014), Bolton et al. (2018); Patrício et al. } \\
\text { (2011) }\end{array}$ \\
\hline Servicescape & $\begin{array}{l}\text { What role do senses play in different servicescapes (e.g. } \\
\text { online vs offline, transformative services)? } \\
\text { Which sequence or simultaneity of sensory perceptions } \\
\text { fosters engagement in the servicescape? } \\
\text { How are CES's dimensions shaping the interaction } \\
\text { between actors in the servicescape? } \\
\text { To what extent are sensory stimuli controllable in the } \\
\text { servicescape? }\end{array}$ & $\begin{array}{l}\text { Nenonen et al. (2018), Rosenbaum and Massiah (2011); } \\
\text { Karpen et al. (2015) }\end{array}$ \\
\hline Outcome measures & $\begin{array}{l}\text { How are sensory stimuli transformed into customer } \\
\text { perceptions? } \\
\text { Is there a spillover between sensory stimuli? } \\
\text { What is the role of prior experiences and/or expectations } \\
\text { on sensory perceptions in the service encounter? } \\
\text { Under what conditions are multisensory richer or less rich } \\
\text { value propositions desired? } \\
\text { How can multisensory CSE be captured or measured? }\end{array}$ & $\begin{array}{l}\text { Agapito et al. (2013/2014); Bolton et al. (2018), Scott } \\
\text { and Uncles (2018), Streicher and Estes (2016) }\end{array}$ \\
\hline Link disconnected research topics & $\begin{array}{l}\text { What are theories and insights about senses from other } \\
\text { fields that are relevant for CSE? } \\
\text { What role do different senses play in a MarTech context? } \\
\text { What is the role of senses for different target groups in } \\
\text { transformative services (e.g. disabled or children vs } \\
\text { elderly)? } \\
\text { Can a lack of senses (e.g. person with impairment or CSE } \\
\text { context with sense restriction) be compensated by other } \\
\text { senses? }\end{array}$ & $\begin{array}{l}\text { Anderson and Ostrom (2015), Beudaert et al. (2017); } \\
\text { Cheung and McColl-Kennedy (2015); Rosenbaum et al. } \\
\text { (2011); Streicher and Estes (2016) }\end{array}$ \\
\hline
\end{tabular}

study - call for future research. First, the authors measure the responses to service stimuli (through cognitive, affective and physical inner responses) and neglect the sensory dimension, which by definition relates to sensory stimuli in the service environment. Second, the measurement of CSE emerges as a second-order construct where the individual dimensions combined measure CSE. However, the findings of this paper suggest that the cause and effect may be much more fertile in that the social, physical and sensorial dimension indicate a potentially subconscious role in the servicescape, whereas the affective and cognitive dimensions most prominently occur with measurable outcome concepts. Accordingly, service research requires investigations that look beyond existing methods by potentially drawing on other fields (such as anthropology) to advance the understanding of CSE and its underlying dimensions.

\section{Form insights into innovating customer service experiences in service systems}

The goal of the service system innovation is to create value through configurations of technologies, people and other resources (Teixeira et al., 2017). Effectively leveraging all three components enable value co-creation (Skålén et al., 2015). Recent studies investigate service innovation from a value-inuse perspective (Yu and Sangiorgi, 2017) because research shows that successful service innovations requires identifying and understanding CSE (Andreassen et al., 2016). Service blueprinting, first introduced by Shostack (1984), orchestrates 
front-and-backstage processes form a customer perspective. This detailed view helps to explain service encounters (Bitner, 1992). Unlike customer product experiences, CSE take place when actors sense and acquire knowledge by interacting with contextual cues (Zomerdijk and Voss, 2010). Thus, the research focus should shift toward a more customer-centric perspective (Jaakkola et al., 2015) or even balanced-centricity perspective (Verleye et al., 2017). The aim of future research should be to provide guidance for successful service system innovations that reinforce multisensory rich value propositions.

\section{Investigate the effects of sensory stimuli in servicescapes}

Despite the importance of CSE to service research (Ostrom et al., 2015; Yu and Sangiorgi, 2017), existing studies have not established how customers derive experiences within the servicescape (Åkesson et al., 2014). While Rosenbaum and Massiah (2011) emphasize that the servicescape constitutes a variety of stimuli that determine customer perceptions and reactions, we know little about how sensory processing of multiple stimuli might translate into desired CSE. Along these lines, Agapito et al. (2014) stress the importance of research on how customers can use sensory stimuli resulting from the environment to derive knowledge and understanding.

\section{Develop a more comprehensive customer service experiences measure}

A lack of understanding exists regarding the influence of sensory perceptions on CSE (Yanagisawa and Takatsuji, 2015). This emerging field of research requires a stronger foundation for understanding how conscious and subconscious stimuli might influence CSE (Bolton et al., 2014). Studies focused on specific performance indicators as proxies for CSE cannot capture the subtle drivers of value creation (Åkesson et al., 2014) or detail the overall experience (Berry et al., 2002). In addition, a common assumption is that customers can articulate the underlying drivers of their experience. This contradicts Helkkula and Kelleher (2010) as they show that each experience is temporal and momentary. The interplay of sensory information prompts customers to form perceptions continuously, throughout the service encounter (Ghanzanfar and Schroeder, 2006), such that assessing a customer experience after the service encounter may result in appraisals that do not reflect the actual CSE at the time customers experienced it (Kristensson et al., 2015).

\section{Reaching out to research areas outside the traditional focus of service research}

The emerging stream on transformative service research (TSR) has encouraged scholars to take different perspectives (Rosenbaum et al., 2011). Among others, two foundational pieces on TSR (Anderson and Ostrom, 2015; Cheung and McColl-Kennedy, 2015) have managed to shift well-being closer to the service researchers' attention. Although customercentricity and designing for excellent CSE are central research and management topics, this focus omits specific target groups (e.g. people with sensory impairment) (Beudaert et al., 2017). For example, future research could investigate how the absence of one's sense can be compensated through the remaining senses. These studies are particularly important to avoid servicescape exclusion (Beudaert et al., 2017). Furthermore, the shift toward omni-channel and MarTech context (Moody et al., 2014) demands studies that explore the role of CSE dimensions in technology-driven online environments.

\section{Managerial implications}

This article analyses the scholarly body of CSE literature, yet, it also holds implications for service managers. First, the findings show the trending themes within CSE, i.e. service system architecture, servicescape, outcome measures and their underlying concepts. Service managers may acknowledge this as the state-of-art CSE to reflect and seize opportunities to improve their services and organizations. An example of such reflections might be the extent in which implemented customer experience measures include the shift from satisfaction and brand perceptions toward emotions and senses. Second, senses are instrumental for customers to capture service perception to gain information and knowledge. Thus, zooming into the sensory dimension enables service managers to identify, understand and design sensory stimuli to establish more valuecreating and meaningful experiences. The relative scarcity of CSE literature capturing the sensory dimensions suggest that interested managers can seek guidance in recent CSE literature or even outside the field of service marketing, for example in psychology, design, or cognitive science. Third, the societal transition from offline to online services is also reflected in our findings, indicating a strong impact on the multi-dimensional role of senses. An online servicescape might not transport all sensory stimuli and their perceptions (e.g. smell), which might in turn be an opportunity for developing better experiences in offline retail settings. At the same time, digital technologies can be advantageous for service providers as they offer enhanced possibilities to test, control and manage sensory stimuli (Trevinal and Stenger, 2014), e.g. eye-tracking. Fourth, the findings of this study point managers toward a more active customer role in the service system, thus helping the co-design of multisensory rich CSE. Service design as an emerging approach offers novel methods such as service blueprinting and sensory ethnography that can facilitate these processes.

\section{Conclusion}

In summary, the present study provides a comprehensive review of CSE literature across leading services and marketing journals over a course of 24 years. By means of a novel systematic, text mining approach, the paper not only presents the status quo in CSE research in the service domain but also presents key avenues for future research that:

- create a more in-depth understanding of CSE's underlying dimensions in complex service systems; and

- broadens the prospective toward emerging research topics such as transformative services.

\section{Limitation}

This article also features some limitations. First, the analysis of this study is based on a systematic literature review of a deliberately selected set of journals from the services and marketing discipline. The goal was not to provide an exhaustive list of publications, but rather provide a comprehensive 
overview on CSE research in services and marketing research. While this paper takes a service research focus, we acknowledge that other disciplines (e.g. design, human-computer interactions, psychology, social and cognitive science) could contribute some additional insights. Furthermore, the samples of CSE articles are bound to keyword selection. In addition, the inclusion criteria required a published article, thus excluding work and other unpublished papers.

\section{References}

Adolphs, R., Damasio, H., Tranel, D., Cooper, G. and Damasio, A.R. (2000), "A role for somatosensory cortices in the visual recognition of emotion as revealed by threedimensional lesion mapping", The fournal of Neuroscience, Vol. 20 No. 7, pp. 2683-2690.

Agapito, D., Mendes, J. and Valle, P. (2013), "Exploring the conceptualization of the sensory dimension of tourist experiences”, Fournal of Destination Marketing and Management, Vol. 2 No. 2, pp. 62-73.

Agapito, D., Valle, P. and Mendes, J. (2014), “The sensory dimension of tourist experiences: capturing meaningful sensory-informed themes in southwest Portugal”, Tourism Management, Vol. 42 No. 1, pp. 224-237.

Åkesson, M., Edvardsson, B. and Tronvoll, B. (2014), "Customer experience from a self-service system perspective", fournal of Service Management, Vol. 25 No. 5, pp. 677-698.

Anderson, L. and Ostrom, A.L. (2015), "Transformative service research: advancing our knowledge about service and well-being", fournal of Service Research, Vol. 18 No. 3, pp. 243-249.

Andreassen, T.W., Kristensson, P., Lervik-Olsen, L., Parasuraman, A., McColl-Kennedy, J.R., Edvardsson, B. and Colurcio, M. (2016), "Linking service design to value creation and service research", fournal of Service Management, Vol. 27 No. 1, pp. 21-29.

Antons, D. and Breidbach, C.F. (2018), "Big data, big insights? Advancing service innovation and design with machine learning", fournal of Service Research, Vol. 21 No. 1, pp. 17-39.

Berry, L.L., Carbone, L.P. and Haeckel, S.H. (2002), "Managing the total customer experience", MIT Sloan Management Review, Vol. 43 No. 3, pp. 85-90.

Berry, L.L., Wall, E.A. and Carbone, L.P. (2006), "Service clues and customer assessment of the service experience: lessons from marketing", Academy of Management Perspectives, Vol. 20 No. 2, pp. 43-57.

Beudaert, A., Gorge, H. and Herbert, M. (2017), "An exploration of servicescapes' exclusion and coping strategies of consumers with "hidden" auditory disorders", fournal of Services Marketing, Vol. 31 Nos 4/5, pp. 326-338.

Biesenthal, C. and Wilden, R. (2014), "Multi-level project governance: trends and opportunities”, International fournal of Project Management, Vol. 32 No. 8, pp. 1291-1308.

Bitner, M.J. (1992), "Servicescapes: the impact of physical surroundings on customers and employees", fournal of Marketing, Vol. 56 No. 2, pp. 57-71.

Bolton, R.N., Gustafsson, A., McColl-Kennedy, J.R., Sirianni, N.J. and Tse, D.K. (2014), "Small details that make big differences: a radical approach to consumption experience as a firm's differentiating strategy", Fournal of Service Management, Vol. 25 No. 2, pp. 253-274.

Bolton, R.N., McColl-Kennedy, J.R., Cheung, L., Gallan, A., Orsingher, C., Witell, L. and Zaki, M. (2018), "Customer experience challenges: bringing together digital, physical and social realms", fournal of Service Management, Vol. 29 No. 5, pp. 1-36.

Brakus, J., Schmitt, B. and Zarantonello, L. (2009), "Brand experience: what is it? How is it measured? Does it affect loyalty?", Fournal of Marketing, Vol. 73 No. 3, pp. 52-68.

Bustamante, J.C. and Rubio, N. (2017), "Measuring customer experience in physical retail environments", fournal of Service Management, Vol. 28 No. 5, pp. 884-913.

Carú, A. and Cova, B. (2015), "Co-creating the collective service experience", fournal of Services Marketing, Vol. 26 No. 2, pp. 276-294.

Cheung, L. and McColl-Kennedy, J.R. (2015), "Resource integration in liminal periods: transitioning to transformative service", Fournal of Services Marketing, Vol. 29 Nos 6/7, pp. 485-497.

Cretchley, J., Rooney, D. and Gallois, C. (2010), "Mapping 40-Year history with leximancer: themes and concepts", fournal of Cross-Cultural Psychology, Vol. 43 No. 3, pp. 318-328.

De Keyser, A., Lemon, N.K., Klaus, P. and Keiningham, T.L. (2015), "A framework for understanding and managing customer experience", Marketing Science Institute, Working Paper Series 2015, Report No. 15-121.

Dinh, H.Q., Walker, N., Song, C., Kobayashi, A. and Hoges, L.F. (1999), "Evaluating the importance of multi-sensory input on memory and the sense of presence in virtual environments", VR '99 Proceedings of the IEEE Virtual Reality in Washington, DC, IEEE Computer Society, pp. 222-231.

Driver, J. and Spence, C. (2000), "Multisensory perception: beyond modularity and convergence", Current Biology, Vol. 10 No. 20, pp. 731-735.

Edvardsson, B., Enquist, B. and Johnston, R. (2005), "Cocreating customer value through hyperreality in the prepurchase service experience", Fournal of Service Research, Vol. 8 No. 2, pp. 149-161.

Garlin, F.V. and Owen, K. (2006), "Setting the tone with a tune: a Meta-analytic review of the effects of background music in retail settings", fournal of Business Research, Vol. 59 No. 6, pp. 755-764.

Gartner (2018), "Key findings from the gartner customer experience survey", available at: www.gartner.com/ smarterwithgartner/key-findings-from-the-gartner-customerexperience-survey/ (accessed 20 September 2018).

Gentile, C., Spiller, N. and Noci, G. (2007), "How to sustain the customer experience: an overview of experience components that co-create value with the customer", European Management Fournal, Vol. 25 No. 5, pp. 395-410.

Ghanzanfar, A.A. and Schroeder, C.E. (2006), "Is neocortex essentially multisensory?", Trends in Cognitive Science, Vol. 10 No. 6, pp. 278-285.

Grewal, D., Roggeveen, A.L. and Nordfält, J. (2017), "The future of retailing", fournal of Retailing, Vol. 93 No. 1, pp. 1-6. 
Gupta, S. and Vajic, M. (2000), "The contextual and dialectical nature of experiences", in Fitzsimmons, J.A. and Fitzsimmons, M.J. (Eds), New Service Development: Creating Memorable Experiences, Sage, Thousand Oaks, CA, pp. 33-51.

Heinonen, K., Strandvik, T. and Voima, P. (2013), “Customer dominant value formation in service", European Business Review, Vol. 25 No. 2, pp. 104-123.

Heinonen, K., Strandvik, T., Mickelsson, K.J., Edvardsson, B., Sundström, E. and Andersson, P. (2010), "A customer dominant logic of service”, fournal of Service Management, Vol. 21 No. 4, pp. 531-548.

Helkkula, A. (2011), "Characterising the concept of service experience", Fournal of Service Management, Vol. 22 No. 3, pp. 367-389.

Helkkula, A. and Kelleher, A. (2010), "Circularity of customer service experience and customer perceived value", fournal of Customer Behaviour, Vol. 9 No. 1, pp. 37-53.

Holbrook, M.B. and Hirschman, E.B. (1982), "The experiential aspects of consumption: consumer fantasies, feelings, and fun", fournal of Consumer Research, Vol. 9 No. 2, pp. 132-140.

Hultén, B. (2011), "Sensory marketing: the multi-sensory Brand-experience concept", European Business Review, Vol. 23 No. 3, pp. 256-273.

Jaakkola, E., Helkkula, A. and Aarikka-Stenroos, L. (2015), "Service experience co-creation: conceptualization, implications and future research directions", fournal of Service Management, Vol. 26 No. 2, pp. 182-205.

Karpen, I.O., Bove, L.L., Lukas, B.A. and Zyphu, M.J. (2015), "Service-dominant orientation: measurement and impact on performance outcomes", fournal of Retailing, Vol. 91 No. 1, pp. 89-108.

Keiningham, T., Ball, J., Benoit (née Moeller), S., Bruce, H.L., Buoye, A., Dzenkovska, J., Alkire (née Nasr), L., Ou, Y.C. and Zaki, M. (2017), "The interplay of customer experience and commitment", Fournal of Services Marketing, Vol. 31 No. 2, pp. 148-160.

Klaus, P. and Maklan, S. (2012), "EXQ: a multiple-item scale for assessing service experience", fournal of Service Management, Vol. 23 No. 1, pp. 5-33.

Krishna, A. (2012), "An integrative review of sensory marketing: engaging the senses to affect perception, judgment and behavior", fournal of Consumer Psychology, Vol. 22 No. 3, pp. 332-352.

Krishna, A. and Schwarz, N. (2014), "Sensory marketing, embodiment and grounded cognition: a review and introduction", fournal of Consumer Psychology, Vol. 24 No. 2, pp. 159-168.

Kristensson, P., Brunstrom, A. and Pedersen, T. (2015), "Affective forecasting of value creation: professional nurses' ability to predict and remember the experienced value of a telemedicine diagnostics ICT service", Behaviour \& Information Technology, Vol. 34 No. 10, pp. 964-975.

Kwon, M. and Adaval, R. (2018), "Going against the flow: the effects of dynamic sensorimotor experiences on consumer choice", Fournal of Consumer Research, Vol. 44 No. 6, pp. 1358-1378.

Li, L.P., Juric, B. and Brodie, R.J. (2018), “Actor engagement valence: conceptual foundations, propositions and research directions", fournal of Service Management, Vol. 29 No. 3, pp. 491-516.

Liesch, P.W., Håkanson, L., McGaughey, S.L., Middleton, S. and Cretchley, J. (2011), "The evolution of the international business field: a scientometric investigation of articles published in its premier journal", Socientometrics, Vol. 88 No. 1, pp. 17-42.

Lipkin, M. (2016), "Customer experience formation in today's service landscape”, fournal of Service Management, Vol. 27 No. 5, pp. 678-703.

Lemon, K.N. and Verhoef, P.C. (2016), "Understanding customer experience throughout the customer journey", Fournal of Marketing, Vol. 80 No. 6, pp. 69-96.

Lusch, R.F., Vargo, S.L. and Gustafsson, A. (2016), "Fostering a trans-disciplinary perspective of service ecosystems", Fournal of Business Research, Vol. 69 No. 8, pp. 2957-2963.

McColl-Kennedy, J., Gustafsson, A., Jaakkola, E., Klaus, P., Radnor, Z., Perks, H. and Friman, M. (2015), "Fresh perspectives on customer experience", Fournal of Services Marketing, Vol. 29 Nos 6/7, pp. 430-435.

Mager, B. (2009), "Touchpoint", Fournal of Service Design, Vol. 1 No. 1, pp. 20-29.

Mattila, A.S. and Wirtz, J. (2001), "Congruency of scent and music as a driver of in-store evaluations and behavior", Fournal of Retailing, Vol. 77 No. 2, pp. 273-289.

Mehrabian, A. and Russell, J. (1974), An Approach to Environmental Psychology, MIT Press, Cambridge, MA.

Moeller, S., Ciuchita, R., Mahr, D., Odekerken-Schröder, G. and Fassnacht, M. (2013), "Uncovering collaborative value creation patterns and establishing corresponding customer roles", Fournal of Service Research, Vol. 16 No. 4, pp. 471-487.

Moody, G.D., Galletta, D.F. and Lowry, P.B. (2014), "When trust and distrust collide online: the engenderment and role of consumer ambivalence in online consumer behavior", Electronic Commerce Research and Applications, Vol. 13 No. 4, pp. 266-282.

Nenonen, S., Gummerus, J. and Sklyar, A. (2018), "Gamechangers: dynamic capabilities' influence on service ecosystems", fournal of Service Management, Vol. 29 No. 4, pp. 569-592.

Netzer, O., Feldman, R., Goldberg, J. and Fresko, M. (2012), "Mine your own business: market-structure surveillance through text mining”, Marketing Science, Vol. 31 No. 3, pp. 521-543.

Nguyen, B., Klaus, P. and Simkin, L. (2014), "It's just not fair: exploring the effects of firm customization on unfairness perceptions, trust and loyalty", fournal of Services Marketing, Vol. 28 No. 6, pp. 484-497.

Orth, U.R. and Malkewitz, K. (2008), "Holistic package design and consumer Brand impressions", Fournal of Marketing, Vol. 72 No. 3, pp. 64-81.

Ostrom, A., Parasuraman, L.A., Bowen, D.E., Patrício, L. and Voss, C.A. (2015), "Service research priorities in a rapidly changing context", fournal of Service Research, Vol. 18 No. 2, pp. 127-159.

Palmer, A. (2010), "Customer experience management: a critical review of an emerging idea", fournal of Services Marketing, Vol. 24 No. 3, pp. 196-208. 
Pareigis, J., Echeverri, P. and Edvardsson, B. (2012), "Exploring internal mechanisms forming customer servicescape experiences", fournal of Service Management, Vol. 23 No. 5, pp. 677-695.

Patrício, L., Fisk, R.P., e., Cunha, J.F. and Constantine, L. (2011), "Multilevel service design: from customer value constellation to service experience blueprinting", fournal of Service Research, Vol. 14 No. 2, pp. 180-200.

Peck, J., Childers, T.L. (2008), "If it tastes, smells, sounds, and feels like a duck, then it must be a....: effects of sensory factors on consumer behaviors", in Haugtvedt, C.P., Herr, P.M. \& Kardes F.R. (Eds), Handbook of Consumer Psychology, Psychology Press, Florence, KY, pp. 193-219.

Pine, B. and Gilmore, J.H. (1998), "Welcome to the experience economy", Harvard Business Review, Vol. 76 No. 4, pp. 97-105.

Prahalad, C.K. and Ramaswamy, V. (2004), "Co-creation experiences: the next practice in value creation", fournal of Interactive Marketing, Vol. 18 No. 3, pp. 5-14.

Randhawa, K., Wilden, R. and Hohberger, J. (2016), "A bibliometric review of open innovation: setting a research agenda", fournal of Product Innovation Management, Vol. 33 No. 6, pp. 750-772.

Roschk, H., Loureiro, S.M.C. and Breitsohl, J. (2017), "Calibrating 30 years of experimental research: a Metaanalysis of the atmospheric effects of music, scent, and color", Fournal of Retailing, Vol. 93 No. 2, pp. 228-240.

Rosenbaum, M.S. and Massiah, C. (2011), "An expanded servicescape perspective", Fournal of Service Management, Vol. 22 No. 4, pp. 471-490.

Rosenbaum, M.S., Corus, C., Ostrom, A.L., Anderson, L., Fisk, R.P., Gallan, A.S., Giraldo, M., Mende, M., Mulder, M., Rayburn, S.W., Shirahada, K. and Williams, J.D. (2011), "Conceptualisation and aspirations of transformative service research", fournal of Research for Consumers, Vol. 19, available at: http://jrconsumers.com/Academic_Articles/ issue_19/Transformative_services_academic5.pdf

Roy, S. (2018), "Effects of customer experience across service types, customer types and time", Fournal of Services Marketing, Vol. 32 No. 4, pp. 400-413.

Schmitt, B.H. (1999), "Experiential marketing", fournal of Marketing Management, Vol. 15 Nos 1/3, pp. 53-67.

Schouten, J.W., McAlexander, J.H. and Koenig, H.F. (2007), "Transcendent customer experience and Brand community", Fournal of the Academy of Marketing Science, Vol. 35 No. 3, pp. 357-368.

Scott, R.O. and Uncles, M.D. (2018), "Bringing sensory anthropology to consumer research", European fournal of Marketing, Vol. 52 Nos 1/2, pp. 302-327.

Shostack, G.L. (1984), "Designing services that deliver", Harvard Business Review, Vol. 62 No. 1, pp. 133-139.

Skålén, P., Gummerus, J., von Koskull, C. and Magnusson, P.R. (2015), "Exploring value propositions and service innovation: a service-dominant logic study", fournal of the Academy of Marketing Science, Vol. 43 No. 2, pp. 137-158.

Smith, A.E. and Humphreys, M.S. (2006), "Evaluation of unsupervised semantic mapping of natural language with Leximancer concept mapping", Behavior Research Methods, Vol. 38 No. 2, pp. 262-279.
Spence, C., Puccinelli, N.M., Grewal, D. and Roggeveen, A.L. (2014), "Store atmospherics: a multisensory perspective", Psychology \& Marketing, Vol. 31 No. 7, pp. 472-488.

Streicher, M.C. and Estes, Z. (2016), "Multisensory interaction in product choice: grasping a product affects choice of other seen products", Fournal of Consumer Psychology, Vol. 26 No. 4, pp. 558-565.

Sunderland, N., Bristed, H., Gudes, O., Boddy, J. and Da Silva, M. (2012), "What does it feel like to live here? Exploring sensory ethnography as a collaborative methodology for investigating social determinants of health in place", Health E Place, Vol. 18 No. 5, pp. 1056-1067.

Svari, S., Slåtten, T., Svensson, G. and Edvardsson, B. (2011), "A SOS construct of negative emotions in customers' service experience (CSE) and service recovery by firms (SRF)", fournal of Services Marketing, Vol. 25 No. 5, pp. 323-335.

Teixeira, J.G., Patrício, L., Huang, K.H., Nóbrega, L. and Constantine, L. (2017), "The MINDS method: integrating management and interaction design perspectives for service design", fournal of Service Research, Vol. 20 No. 3, pp. 240-258.

Trevinal, A.M. and Stenger, T. (2014), "Toward a conceptualization of the online shopping experience", Fournal of Retailing and Consumer Services, Vol. 21 No. 3, pp. 314-326.

Wetter-Edman, K., Sangiorgi, D., Edvardsson, B., Holmlid, S., Grönroos, C. and Mattelmäki, T. (2014), "Design for value co-creation: exploring synergies between design for service and service logic", Service Science, Vol. 6 No. 2, pp. 106-121.

Wilden, R., Akaka, M.A., Karpen, I.O. and Hohberger, J. (2017), "The evolution and prospects of service-dominant logic: an investigation of past, present, and future research", Fournal of Service Research, Vol. 20 No. 4, pp. 345-361.

Vargo, S.L. and Lusch, R.F. (2004), "Evolving to a new dominant logic for marketing", fournal of Marketing, Vol. 68 No. 1, pp. 1-17.

Vargo, S.L. and Lusch, R.F. (2008), "Service-dominant logic: continuing the evolution", Fournal of the Academy of Marketing Science, Vol. 36 No. 1, pp. 1-10.

Vargo, S.L. and Lusch, R.F. (2016), "Institutions and axioms: an extension and update of service-dominant logic", Fournal of the Academy of Marketing Science, Vol. 43 No. 1, pp. 5-23.

Verleye, K., Jaakkola, E., Hodgkinson, I.R., Jun, G.T., Odekerken-Schröder, G. and Quist, J. (2017), "What causes imbalance in complex service networks? evidence from a public health service", fournal of Service Management, Vol. 28 No. 1, pp. 34-56.

Yakhlef, A. (2015), "Customer experience within retail environments: an embodied, spatial approach", Marketing Theory, Vol. 15 No. 4, pp. 545-564.

Yanagisawa, H. and Takatsuji, K. (2015), "Expectation effect of perceptual experience in sensory modality transitions: modeling with information theory", fournal of Intelligent Manufacturing, Vol. 9 No. 1, pp. 1-10.

Yu, E. and Sangiorgi, D. (2017), "Service design as an approach to implement value cocreation perspectives in new service development", fournal of Service Research, Vol. 21 No. 1, pp. 1-19. 
Zomerdijk, L.G. and Voss, C.A. (2010), "Service design for experience-centric services", fournal of Service Research, Vol. 13 No. 1, pp. 67-82.

\section{Further reading}

Kranzbühler, A.M., Kleijnen, M.H.P., Morgan, R.E. and Teerling, M. (2018), "The multilevel nature of customer experience research: an integrative review and research agenda", International fournal of Management Reviews, Vol. 20 No. 2, pp. 433-456.

Levy, S.J. (1996), "Stalking the amphisbaena", Fournal of Consumer Research, Vol. 23 No. 3, pp. 163-176.

Teixeira, J., Patrício, L., Nunes, N.J., Nóbrega, L., Fisk, R. P. and Constantine, L. (2012), "Customer experience modelling: from customer experience to service design", Fournal of Service Management, Vol. 21 No. 1, pp. 362-376.

\section{About the authors}

Dominik Mahr is a Professor of Digital Innovation and Marketing at Maastricht University and the Scientific Director of the Service Science Factory (SSF). His research centers on digital marketing, service design, co-creation and innovation management. His research has been published in journals such as Fournal of Marketing, MIS Quarterly, Fournal of the Academy of Marketing Science, Fournal of Retailing, Fournal of Service Research, Fournal of Service Management, Fournal of Business Research and fournal of Product Innovation Management. Prior to his academic career, Dominik worked for several years in different management and marketing consultancies. Dominik Mahr is the corresponding author and can be contacted at: d.mahr@maastrichtuniversity.nl

Susan Stead is a PhD Candidate at the Department of Marketing and Supply Chain Management at Maastricht University, The Netherlands. Her research centers on customer service experiences, with a particular focus on multisensory perception.

Gaby Odekerken-Schröder is a Professor in Customercentric Service Science at Maastricht University, The Netherlands. Her main research interests are service innovation, relationship management, customer loyalty and service failure and recovery. Professor OderkerkenSchroder has published her work in the fournal of Marketing, MISQ, Fournal of Retailing, Fournal of Service Research, Fournal of Service Management, Fournal of Business Research and many more. 